\title{
The Application of the Peer Tutoring Method in the Basic Nursing Science II Course
}

\author{
Dewi Murni ${ }^{1,{ }^{*}}$ Nelwati $^{1}$ Zifriyanthi Minanda Putri ${ }^{1}$ Esthika Ariany Maisa ${ }^{1}$ \\ Ilfa Khairina ${ }^{1}$ Sidaria $^{1}$ Yuanita Ananda ${ }^{1}$
}

Faculty of Nursing, Universitas Andalass

${ }^{*}$ Corresponding author. Email: dewimurni.mkep@gmail.com

\begin{abstract}
Peer tutoring is a flexible, peer-mediated strategy that involves students acting as tutors and academic tutors. The Study Lab tutors serve as guides and mentors to help students become successful independent learners. Tutors support students in developing attitudes, behaviors, and understanding of the material. Tutors integrate study strategies and effectiveness of study to maximize potential tutee for academic progress and success. As members of the tutor team, the tutor maintains ongoing communication with the tutor program coordinator. The nursing faculty has shared study rooms and classrooms with a laboratory and WI-FI at the IKD 2 practicum. Each student has a module as a reference for the implementation of the practical with the Peer tutoring method. Previous learning methods were demonstration and evaluation as well as case studies. At the end of the student practical lecture, an evaluation is carried out simultaneously for one or more days. Based on the results of the evaluation, the students were less courageous and creative and skilled. With the implementation of Peer tutoring, students are more courageous and skilled in doing nursing actions. The average evaluation result was 89.6 percent. It is hoped that with Peer tutoring method students will be more courageous and have the ability to participate independently, so that in the final exams the skills and knowledge of the students can increase and have more critical thinking in implementing nursing care.
\end{abstract}

Keywords: Application, Peer tutoring, IKD II

\section{INTRODUCTION}

The peer tutorial method is part of cooperative learning or learning together. In this model, underprivileged students are helped to study by their more capable peers in a group. Edward L. Dejnozken and David E. Kopel in the American Education Encyclopedia stated that the definition of peer tutor is as follows: Peer tutor is a procedure for students to teach other students. Learning together in groups with peer tutors is one of the characteristics of competencybased learning, through interaction and communication activities, students become active in learning, so they become effective. Some of the types used in the implementation of Peer tutoring are the first type with the same age. Second type is a teacher who is older than the learner.

The term of peer tutorial referred to in this study is how to optimize the ability of outstanding students in a small group to teach or transmit to their underachieving peers. So that the underachieving students can overcome being left behind. Guidance in lessons provided by a student to other students, while they (between the supervisor and the mentored) are classmates or colleagues who are relatively the same age, and students who do not understand can ask directly to the friend who represents (the tutor appointed) so that condition in the class can be alive because the students are not ashamed to ask questions 
The Peer tutoring method is a learning that is done by empowering students from the student group themselves to become tutors for their friends, where students who become tutors are tasked with providing learning material and training to their friends (tutee) who do not understand with the material / the training given by the lecturer. This is based on the rules that have been mutually agreed upon in the group, so that a cooperative, not competitive, group learning atmosphere will be developed.

The rapid development of nursing science is that nursing care uses Nursing Care 4.0 where nurses must be ready to compete with the outside of the world. Skills and knowledge are not sufficient with theory without being based on nursing practices. The learning that has been carried out is in the form of Ilearn and online to improve the competence of students. Researchers carry out the practical learning method using the Peer Tutoring method.

Learning together in groups with peer tutors is one of the characteristics of competency-based learning, through interaction and communication activities, students become active in learning so they become effective. Collaboration in groups with peer tutors can be linked to values so that cooperation is more intensive and students can achieve their competence. In terms of the level of active student participation, the advantages of studying in groups with peer tutors are having a higher student active participation rate. According to Thomson, the learning process does not have to come from teacher to student, but can also teach each other tutees.

Student competence will be more skilled if students are provided with this peer tutor method. Students who have similar abilities must have the same understanding of the material and content concepts. Tutors support students in developing appropriate attitudes, behaviors, and understanding of learning materials. Tutors integrate study strategies and effectiveness of study to maximize the potential of the tutee for academic progress and success. As members of the tutor team, the tutor maintains ongoing communication with the tutor program coordinator.

This peer tutoring model is flexible and can be changed to meet the learning needs of individual students or classes.
Academic assignments must determine an appropriate model based on the content and learning objectives. Although there is some planning and advance instruction, once students develop an understanding of the procedure, groups or pairs can be changed depending on the desired setting, activity, or learning outcome.

With this peer tutoring method will strengthen the abilities and skills of students and the results of lab exams can be evaluated maximally and already have the basic provisions for practicing pre-clinics and are ready to carry out professions and exams before entering the nurse profession.

\section{BACKGROUND}

Humans as holistic beings mean human beings that consist of biological, psychological, social and spiritual elements, or often referred to as spiritual biopsychosocial beings. When one of these elements experiences obstacles, the other elements will have an impact. Basic Nursing II courses are courses that include the core structure of the S1 Nursing study program which consists of 3 credits $(2 \mathrm{~T}, 1 \mathrm{P})$. This IKD II subject is also the basis for the implementation of nursing care that is studied by students. Students must be skilled and competent in honing skills and knowledge must go hand in hand.

This course discusses various nursing concepts, principles and clinical skills to help meet a variety of human needs, including activities and training needs; oxygenation requirements; fluid, electrolyte and fluidelectrolyte balance requirements; rest and sleep needs; nutritional needs; elimination needs; comfort needs; hygiene and personal care needs. Learning experiences include learning in the classroom and in the nursing laboratory. This competency is the foundation and basic provision for students to go to the clinic, health center and hospital. Armed with this competency, students do not feel awkward in carrying out nursing care and are ready to compete in the outside world.

This method is applied in the IKD (basic nursing science II course for the 2019-2020 academic year even with the number of 51 local people. One batch is divided into 7 small groups, of which seven groups will represent each group to become one peer group that will get enlightenment from the facilitator. In previous years this method has not been implemented, over time this peer 
tutoring method can increase the courage of students in discussing and debating opinions and cases.

Peer tutoring is a flexible, peer-mediated strategy that involves students acting as tutors and academic tutors. The Study Lab tutors serve as guides and mentors to help students become successful independent learners. Tutors support students in developing attitudes, behaviors, and understanding of the material. Tutors integrate effective study and study strategies to maximize potential tutee for academic progress and success. As members of the tutor team, the tutor maintains ongoing communication with the tutor program coordinator. Based on the results of research (Ruseno, 2010) states that the peer tutor learning method has a contribution of 17.4 percent in improving student learning outcomes based on self- regulation. This research proves that active learning can be done without spending a lot of time and shortens the time spent and students have a lot of time. In addition, the learning process can be maximized with existing potential, including through peer tutors.

The nursing faculty has shared study rooms and classes with a laboratory and WI-FI. During the IKD 2 practicum, students can borrow tools according to the competencies that need to be practiced. This course is developed in the form of modules. Each student has this module as a reference for the implementation of practicum with the Peer Tutoring method. Previous learning methods were demonstration and evaluation as well as case studies. At the end of the student practicum lecture, an evaluation is carried out simultaneously for one day. Based on the results of the evaluation, the students were less courageous and creative and skilled. It is hoped that with this Peer Tutoring method students will be more courageous and have the ability to participate independently, so that in the final exams, student's skills and knowledge can increase and have more critical thinking in implementing nursing care.

\subsection{Methodology and Strategy External Achievement}

Research development and education quality assurance (PPMP) aims to increase activeness, hone student skills and knowledge as well as independence in carrying out nursing actions. In Industry 4.0, students must be ready to compete intelligently and brilliantly. Then improving student learning outcomes through the application of the
Peer tutoring learning method. The output of this research is the formulation of a new semester learning plan (RPS) using peer tutoring strategies and publication of scientific articles related to this learning method.

Briefly, external methods and strategies will be explained as follows:

\subsubsection{Research Design}

Research is a change in the method of guidance and facilitators in implementing the basic human needs practicum which is in the basic nursing science II course. By using the Peer Tutoring method according to Harper \& Maheady, 2007 the number of students in each team must be determined. The student list can then be numbered from one to the desired number of people in a group and then repeated until the entire class is entered

\subsubsection{Research Subjects and Objects}

The subjects of this study were all students of the Undergraduate Nursing Study Program at the Nursing Faculty of Andalas University in the 2019-2020 academic year. In the even semester who takes basic nursing science courses II. This class consists of class 3 (three) classes, namely classes 1,2 and 3 , totaling 155 people in semester two. Those who will be used as research subjects based on cluster sampling are 60 people, each in the same class as 20 students. While the object of this research is the peer tutoring method to improve the skills and knowledge of students in the application of nursing care both individually and in groups.

\subsubsection{Data Collection Techniques}

This research will be conducted during March-August 2019, where pre-research data will be collected in the 4th week of April 2019. The pre-research data is used to get the latest information for the implementation of Peer tutor learning. Cycle one will be held in the 3rd week of May 2019, and cycle two will be held in the 4th week of May. Research data collection techniques will be carried out through action, evaluation by observation.

\subsubsection{Data Analysis Techniques}

The data analysis technique that will be used is to use triangulation data. Student learning outcomes data will be analyzed using descriptive statistical techniques. 
Student learning outcomes data will be used to evaluate the success of implementing the peer tutoring strategy through changes in student learning outcomes. Data from the observation action will be analyzed qualitatively.

\subsubsection{Research Flow}

The flow of this research will refer to the head of the research roadmap. The research roadmap focuses on several stages

a. Establish topics and procedures

b. Determine the facilitator and share the responsibility for each competency of each lecturer

c. Establish peer tutor groups quickly and represent a peer group

d. Describe and model peer tutoring and allow students to practice before the first peer tutoring session. Consider using scripts prepared to practice interactions (Fulk \& King, 2001).

e. Train students how to provide feedback for correct and incorrect peer responses, including praise.

\subsubsection{Strategies External Achievement}

The external achievement strategy that will be done refers to the principles of peer tutoring, namely:

\section{a. Learning Plan Semester (RPS)}

The existing RPS for Basic Nursing II courses will be changed using the Peer tutoring method. The peer tutoring process will be carried out based on actions, before the course of action, the course team prepares modules. Associated with basic nursing actions II course. A significant aspect that will change is in this aspect of the learning strategy is independent action in carrying out basic actions. So that skills and abilities in carrying out basic actions are more refined and ready to go down to the field, both at the public health center and the associated hospitals. And the final laboratory exam results can be satisfactory. Aspects that must be developed and trained in this learning process are independent learning and practice.

\section{b. The Learning Strategy}

This strategy that will be developed is a learning strategy based on activeness, demonstration and simulation with the peer learning method. The reason for choosing this method as a problem solving solution with practical groups of more than 12 per group consisting of 12-13 people in one group and maximizing time in the action process so that students can be evaluated regularly. Based on this, the development team considered it appropriate to use this method to improve student skills in nursing care contained in basic nursing science II.

\section{c. The Steps}

This steps that the development team will take in this Peer tutoring learning strategy are: 1) Determining which learning outcomes will be carried out in face-to- face and practicum, and which parts use online, the Ilearn exam. The considerations used in determining learning outcomes using Peer tutoring are dependent on the results of the competence to be produced, and the readiness of students to step down in the field 2). Completing the method of delivering the action using the completed view data in the form of basic nursing science modules II. This is very much supported by laboratory support tools.

\subsection{Evaluation Criteria}

The assessment is carried out on the process and output aspects. For the process aspect, it is assessed the success of implementing the Peer learning strategy through changes in student learning outcomes including the average score of assignments and group participation, midterm exams and end-semester tests. Output assessment is in the form of independence in carrying out actions, and can analyze actions based on nursing care through observation.

The independence assessment includes five components of assessment, namely: 1) the ability to take initiative, either with or without the help of others, to diagnose their learning needs, 2) the ability to formulate learning goals, 3) the ability to identify learning resources, whether in the form of humans or goods / materials, 4 ) The ability to choose and implement learning strategies that are suitable for themselves, and 5) The ability to evaluate learning outcomes by themselves.

Meanwhile, the assessment of critical thinking ability is seen from the 13 assessment elements, namely; 1) Open minded, 2) Take a stand when 
evidence and reason are sufficient, 3). Consider the whole situation, 4). Equip yourself with information, 5). Looking for as much truth/ accuracy as possible, 6). Solve problems systematically and thoroughly, 7). Looking for alternatives, 8). Looking for reasons / causes, 9). Looking for a clear statement of a problem, 10). Remember the main / basic things, 11). Use a credible source and mention it, 12). Trying to be relevant to the main idea, 13). Sensitive to other people's feelings, knowledge levels, and ability levels

\section{RESEARCH RESULTS}

At this stage, the results of data analysis will be described, namely student cognitive learning includes a description of the UTS and UAS exam results as well as practical scores. The results of the evaluation of the level of student satisfaction based on the peer tutoring method. Students are divided into groups and have the responsibility of each group that has been determined. After peer tutoring, students feel enthusiastic and have the confidence to share and accompany the team to take action. The learning process is recommended for students to have references and knowledge in writing and also to use audio with predetermined topics. This process has a positive impact on the team so that it maximizes time and competence that is flexible enough for students to take action.

This research runs according to plan, all teaching teams that are already involved in carrying out their respective duties and responsibilities. Implementation of tutoring Peer, no problem by the teaching team. Based on interviews with teams, this method is very helpful for students to quickly understand the action. Before entering the meeting, students are encouraged to study independently and understand the observation data and modules that have been provided.

Assignments and information via WhatsApp telephone, email, and Ilearn. The UTS exam process has been completed which was held in May with an average class score of 67.42. Early June 2020, the implementation of the UAS exam, the exam was conducted through Ilearn with a class average score of 68.78. meanwhile, the score of the results of the practicum exam which is based on Peer Tutoring is 89.6 Percent
Table 1. Aspect Assessment Assurance

\begin{tabular}{|ll|l|l|}
\hline No & Information & Assessment & $\begin{array}{l}\text { Percen } \\
\text { tage }\end{array}$ \\
\hline 1 & $\begin{array}{l}\text { Guarantee / treatment } \\
\text { of students in terms } \\
\text { of the ability of the } \\
\text { lecturer to use the } \\
\text { method / model of } \\
\text { learning peer tutoring }\end{array}$ & Satisfying & 54,1 \\
\hline 2 & $\begin{array}{l}\text { Lecturer emphasis in } \\
\text { ending the practicum }\end{array}$ & Satisfying & 67,2 \\
\hline 3 & $\begin{array}{l}\text { The clarity of the } \\
\text { lecturer in delivering } \\
\text { practical topics, }\end{array}$ & Satisfying & 55,7 \\
\hline 4 & $\begin{array}{l}\text { Number of lecturer } \\
\text { meetings } \\
\text { delivering material }\end{array}$ & Satisfying & 50,8 \\
\hline
\end{tabular}

Table 2. Aspect Assessment Reliability

\begin{tabular}{|c|c|c|c|}
\hline No & Information & Assessment & $\begin{array}{l}\text { Percen } \\
\text { tage }\end{array}$ \\
\hline 1 & $\begin{array}{l}\text { Accuracy in dividing } \\
\text { peer tutoring groups }\end{array}$ & Satisfying & 57,4 \\
\hline 2 & $\begin{array}{l}\text { A description of the } \\
\text { peer tutoring } \\
\text { function }\end{array}$ & Satisfied & 45,9 \\
\hline 3 & $\begin{array}{l}\text { Providing teaching } \\
\text { materials } \\
\text { (assignments and e- } \\
\text { modules) by the } \\
\text { lecturer to } \\
\text { complement the } \\
\text { material }\end{array}$ & Satisfying & 50,8 \\
\hline 4 & $\begin{array}{lr}\text { Submission } & \text { of } \\
\text { assignments } & \text { and } \\
\text { feedback } & \text { from } \\
\text { lecturers } & \end{array}$ & Satisfying & 62,3 \\
\hline 5 & $\begin{array}{l}\text { Clarity of procedures } \\
\text { in carrying out } \\
\text { actions }\end{array}$ & Satisfying & 47.5 \\
\hline
\end{tabular}




\begin{tabular}{|l|l|l|l|}
\hline 6 & $\begin{array}{l}\text { Availability of space } \\
\text { for independent } \\
\text { practicum }\end{array}$ & Good enough & 39,3 \\
\hline 7 & $\begin{array}{l}\text { Opinion about the } \\
\text { peer tutoring method }\end{array}$ & Good enough & 41.5 \\
\hline 8 & $\begin{array}{l}\text { The ability of the } \\
\text { lecturer in using } \\
\text { media and tools in } \\
\text { practicing the } \\
\text { practice Satisfying }\end{array}$ & 47.5 \\
\hline
\end{tabular}

From the Aspect of Empathy (Understanding of student interests). The willingness of lecturers to help students who are facing obstacles $45.9 \%$ is satisfactory). The ease of contact for lecturers by telephone, email, WhatsApp and so on was $41 \%$. The openness and cooperative attitude of lecturers and students was $54.1 \%$ satisfactory. The number of lecturers' meetings was $50.95 \%$ satisfactory delivering material.

Based on the results of the student evaluation above, the peer tutoring method is very appropriate and more effective for students. Peer learning is a broad learning strategy, with the results of the research that Peer tutoring is a highly effective way for the students to learn from each other. It does not only benefit the students academically, but also helps the students in developing their communication and interpersonal skills (Ali, 2015).

Peer Guidance is a very effective way for students to learn from one another and increase academic grades (Irfan, 2018). This peer tutoring method is also very beneficial for students academically. Based on Yusuf's research, (2017) this study reveals that peer tutoring instructional strategy has a significant effect on students' academic performance. Helping students develop academic communication. Improve students' interpersonal skills. Through methods. This Peer tutoring will increase students' confidence and they will become motivated to take action.

Peer tutoring is often known as peer learning or among students. According to Abu Ahmad and Widodo Supriyono (Haryati 2019), peer tutoring of students who learning difficulties, because the relationship between friends is generally closer than the relationship between teacher and students. Then, according to Ischak 1987: Haryati 2019) classmates who have completed the material provide assistance to students who have difficulty understanding the material being studied. In the sense that students can help friends who do not understand, so that learning activities will occur in an active, communicative and fun learning process.

Based on the results of research conducted by (Haryati 2019), it was stated that there was an increase in student cognitive learning outcomes by applying the peer tutor method. Supported by research by Alwi, Muhammad Muhib (2009) and Ika Martalita Sari (2006) that the use of using peer tutoring methods is more effective. In Kaufman, Felder and Fuller, peer learning allows students to develop their skills in interacting and planning learning activities, working in collaboration with others. As well as providing feedback and evaluation of their own results.

Based on the researcher's analysis, this method is better and more appropriate to use in nursing care actions, especially in nursing actions. This is supported by Friska's research (2017) Learning by using peer tutoring methods have managed to improve student's understanding of environmental chemicals. Tutee was more relaxed in issuing opinions to the tutors in their groups. Peer tutoring methods were expected to be the solution for a fun learning. Learning by using peer tutoring methods was able to activate students in the group. Mastery learning outcomes of students by using peer tutoring methods of $76 \%$. There should be freedom and self-confidence for students to gain knowledge and apply knowledge.

\section{CONCLUSION}

The Peer Tutoring learning method is very appropriate and more effective for students in doing practical nursing actions. The Peer Tutoring learning method has a positive impact on the Teaching team and students and maximizes time in doing nursing actions. This Peer tutoring method is also very beneficial for students academically. The ability of the lecturer in using the Peer tutoring learning model is satisfactory. The teaching team's reliability in the implementation of Peer tutoring in group division was also satisfactory.

\section{AUTHORS' CONTRIBUTIONS}

The author provides an effective method in implementing the practicum in the next semester. 


\section{ACKNOWLEDGMENT}

Learning with this peer tutoring method can improve student's skills and knowledge in practicing nursing action. Tutee is also freer in expressing and expressing opinions in small groups. This peer tutoring method is expected to be a solution for practical learning that is fun for students.

\section{REFERENCES}

[1] Ahda, Haryati. (2019). Peer Tutoring Methods in Improving Cognitive Learning Outcomes. Edutech Consultant Bandung AKSARA PUBLIC Journal Volume 3 Number 1 February 2019 Edition (73-80).

[2] Ali, Najabat. 2015. Impact of Peer Tutoring On Learning of Students. Journal for Student in Management and Planning (JSMAP) IJR EISSN: 2395-0463 Volume 01 Issue 02.

[3] Gazula, Swapnali. (2016). A Systematic Review of Reciprocal Peer Tutoring Within Tertiary Health Profession Educational Program, www.sciencedirect health profession education 3.

[4] Hardisman. (2015). Physiology and Clinical Aspects Body fluids and electrolytes

[5] Jacob, A., Rekha R., \& Tarachnand, J.D. (2014). Clinical Nursing Procedures textbook. Second Edition. Volume 1. Tangerang Selatan : Bina Rupa Aksara Publisher (Indonesian).

[6] Komite Keperawatan RSUP Dr. M. Djamil Padang.(2016).Checklist of Nursing Student Competencies.

[7] Kozier, Barbara. (2015). Fundamentals of Nursing: Concepts, Process and Practice. $3^{\text {th }}$ ed. New Jersey. Pearson Education.

[8] Kozier, B., Erb, G., Berwan, A.J., \& Burke,K. (2008). Fundamentals of Nursing: Concepts, Process, and Practice. New Jersey: Prentice Hall Health.

[9] Lynn, P. (2011). Taylor's Handbook of Clinical Nursing Skills. 3rd ed. Wolter Kluwer, Lippincott Williams \& Wilkins. Philadelphia.

[10] Maryunani, Anik. (2011). Basic Clinical Practice Skills.

[11] Cv Trans Info Media ISBN: 978-602-202-032-5.

[12] Mosby. (2014). Mosby's Nursing Video Skills DVD Package: Basic, intermediate and advanced. 4th Edition. Mosby: Elsevier Inc.

[13] Potter, P.A. \& Perry, A.G. (2010). Fundamental Keperawatan (3-vol set). Edisi Bahasa Indonesia 7. Elsevier (Singapore) Pte.Ltd.

[14] Perry A.G., Potter P.A., Ostendorf W. (2014). Clinical Nursing Skills and Techniques. $8^{\text {th }}$ edition. Mosby: Elsevier Inc.
[15] Ruseno (2010) Peer Tutor Learning Methods Improve Learning Outcomes. Regulasi-Diri. https://en.wikipedia.org/wiki/Peer_tutor di akses pada tanggal 16 maret 2020.

[16] Silitonga, Friska, 2017, The Using of Peer Tutoring Learning Method in Improving Student's Understanding, Advances in Social Science, Education and Humanities Research, volume 174, (ICE 2017)

[17] Ullah, Irfan. (2018). Effects of Peer Tutoring on The Academic Achievement of Students in The Subject of Biology at Secondary Level. www.mdip.com/journal/education 